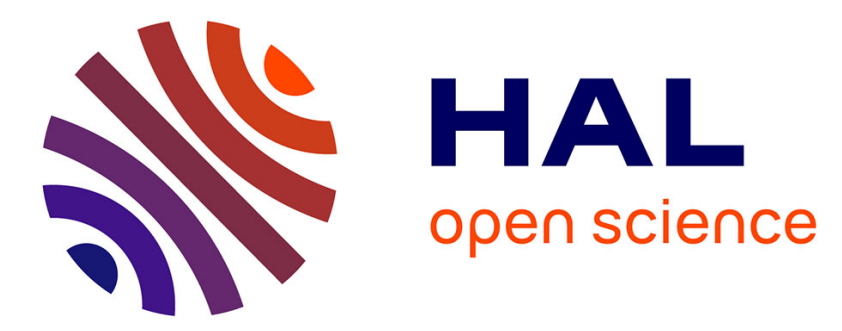

\title{
Conservation, ecology, restoration, and management of Mediterranean pines and their ecosystems: challenges under global change
}

Rigolot

\section{- To cite this version:}

Rigolot. Conservation, ecology, restoration, and management of Mediterranean pines and their ecosystems: challenges under global change. Annals of Forest Science, 2012, 69 (4), pp.417-419. 10.1007/s13595-012-0221-4 . hal-00930870

\section{HAL Id: hal-00930870 https://hal.science/hal-00930870}

Submitted on 1 Jan 2012

HAL is a multi-disciplinary open access archive for the deposit and dissemination of scientific research documents, whether they are published or not. The documents may come from teaching and research institutions in France or abroad, or from public or private research centers.
L'archive ouverte pluridisciplinaire HAL, est destinée au dépôt et à la diffusion de documents scientifiques de niveau recherche, publiés ou non, émanant des établissements d'enseignement et de recherche français ou étrangers, des laboratoires publics ou privés.

$$
\text { Copyright }
$$




\title{
Conservation, ecology, restoration, and management of Mediterranean pines and their ecosystems: challenges under global change
}

\author{
Eric Rigolot
}

Received: 11 May 2012 / Accepted: 16 May 2012 /Published online: 14 June 2012

(C) INRA / Springer-Verlag France 2012

Initiated in 1999 in Mt. Carmel in Israel, the cycle of MEDPINE conferences has already traveled to Chania in Greece (Arianoutsou and Thanos 2004) and Bari in Italy (Leone and Lovreglio 2007). The fourth edition of the conference was organized in June 2011 by the research group on Ecology of Mediterranean Forests from INRA Avignon, France, and was entitled "Conservation, Ecology, Restoration and Management of Mediterranean Pines and their Ecosystems: Challenges under global change." The main emphasis of the conference was placed on the euMediterranean pine species Pinus halepensis, Pinus brutia, Pinus pinea, Pinus sylvestris, Pinus pinaster, and Pinus canariensis, but contributions relating to other pines of the Mediterranean mountains (Pinus nigra, Pinus mugo, Pinus uncinata, and Pinus heldreichii) or from other regions under the Mediterranean bioclimate were also presented.

All together, the Mediterranean pines represent a group of species of key importance not only because of their contribution to planted and natural woodlands in the Mediterranean basin (13 million ha), but also because of their high ecological and economical values (Sheffer 2012).

The main objective of the conference was to bring together researchers of all disciplines studying Mediterranean pines in order to bring forward available knowledge, identify research gaps, and make recommendations for sustainable management. The climate change context was an added complexity for all the attendees, and a special session was dedicated to this issue.

\section{Handling Editor: Erwin Dreyer}

\section{E. Rigolot $(\triangle)$}

INRA, UR629, Ecologie des Forêts Méditerranéennes (URFM),

Site Agroparc, Domaine St Paul,

84914 Avignon cedex 9, France

e-mail: eric.rigolot@avignon.inra.fr
More than 150 participants from 14 countries attended the MEDPINE 4 conference in Avignon, substantially more than the previous editions. The conference program was built to stimulate a multidisciplinary dialog and to strengthen the research community working on a common object, Mediterranean pines. Fifty-two oral communications and more than 100 posters were presented in sessions dealing with ecology, genetics and breeding, pine and insect interactions, stand dynamics and forest management, ecophysiology, fire sciences, and climate change.

An exhaustive synthesis of the main results of the conference was published for French readers in Forêt Méditerranéenne (Rigolot et al. 2012). This thematic issue of Annals of Forest Science comprises nine original papers including three review papers, selected to present a sample of the most significant scientific results.

The first three papers address Mediterranean pine dynamics. Pines are mostly pioneer species colonizing disturbed sites or expanding from existing stands or past plantations (Sheffer 2012). Pine expansion in the Mediterranean region is favored by harsh local conditions, high disturbance pressures, and important land use changes. Accordingly, many studies were carried out to disentangle the effects of land use, environmental conditions, and climate on pine expansion (e.g., Boulant et al. 2009). Piermattei et al. (2012) discuss the relative importance of climate compared to land use changes, such as decreased grazing, on the spatiotemporal expansion dynamics of $P$. nigra at tree line in the Central Apennines. Coutts et al. (2012) address the reproductive ecology of an exotic population of P. nigra Arn. ssp. laricio in New Zealand which behaves as an invasive species in this part of the world. They conclude on the key role of two opposite features impacting the dynamics of these invasive pines: right-skewed fecundity distributions may slow pine rate of spread, while preferential release of seeds 
when conditions are dry and windy is likely to increase spread rate.

Pine expansion is one of the processes leading to pineoak communities. Through a literature review, Sheffer (2012) analyses the processes and pathways leading to this mixed mosaic and concludes that pine-oak colonization still does not form a completely novel ecosystem, but rather a hybrid system. However, this highly dynamic system requires an adaptive management approach and new policies optimizing ecosystem services.

In this context, De-Miguel et al. (2012) address the issue of predicting stand dynamics in forest management and planning. They identified the best modeling approach to estimate the growth of $P$. brutia when past silviculture led to complex stand structures that cannot be easily classified as even aged or uneven aged.

The next four papers are related to fire science. With the objective of better understanding the resilience of $P$. pinaster communities to wildfire disturbance, Maia et al. (2012) analyze the factors driving post-fire recruitment of pine woodlands and underline the predominant role of fire severity. Vasques et al. (2012) show the importance of seed provenance on the fire ecology of typical understory species. Whereas these two studies are carried out at the stand level, Poirazidis et al. (2012) address a wider area and propose an integrated GIS-based model to predict post-fire Aleppo pine regeneration at a regional scale. The approach combines a multicriteria analysis to select the most important factors explaining post-fire pine seedling density and a geostatistical analysis of forest regeneration dynamics.

At the interface between fire ecology and evolution, Keeley (2012) draws up a review of paleoenvironmental history of Mediterranean pines worldwide and proposes an evolutionary classification of the two Pinus lineages (subgenera Pinus and Strobus) where fire is seen as a major driving factor, as important as climate or environmental conditions. The author identifies several adaptive strategies to different fire regimes explaining part of the current Mediterranean pine distribution.

Remaining in the field of evolutionary history of pines, but focusing on species living in the Mediterranean basin, Fady (2012) addresses their within- and among-population genetic diversity using a biogeographic and phylogenetic approach. The author highlights the record level of differentiation of Mediterranean pines and discusses the factors contributing to their decreasing genetic diversity from east to west and to their low diversity at low elevation.

Still in the field of genetics, the last paper uses a large number of genetic trials planted for breeding purposes along an Atlantic-Mediterranean gradient in Galicia (NW Spain) to improve the understanding of $P$. pinaster response to climate change (de la Mata et al. 2012). Strong genetic $\times$ environment interactions were found, but with no clear geographical patterns. Only the cold regime appeared to significantly modulate phenotypic plasticity. In the context of climate change, these results make it possible to consider transferring improved material from coastal to Mediterranean areas.

This sample of results, originating from various disciplines, illustrates the dynamism of the research activities on Mediterranean pines, making them a good study model for forestry science in a climate change perspective. The MEDPINE network is a pillar of the Mediterranean forest research community which builds bridges between Southern Europe, Northern Africa, and the Middle East. The next MEDPINE conference will perpetuate this legacy and will be held in 2014 in Solsona, Catalonia, Spain, co-organized by the Forest Technology Centre of Catalonia and the Sustainable Forest Management Research Institute (CIFOR-INIA) in Madrid.

Acknowledgments I thank the members of the international scientific committee of the conference, Margarita Arianoutsou, Melih Boydak, Philippe Dreyfus, Bruno Fady, Paulo Fernandes, Roland Huc, Abdelhamid Khaldi, François Lefèvre, Vittorio Leone, Gidi Ne'eman, Costas A. Thanos, and Ramon Vallejo. I also acknowledge the contribution to the success of the conference of the members of the local organizing committee, Marie-Claude Bouhedi, Annie Foll, Anne Glémin, and Laurent Mougin. Finally, I wish to acknowledge the authors' efforts and all the reviewers of this special issue papers.

Funding The conference was funded by the French National Institute for Agricultural Research (INRA), the city of Avignon, the Vaucluse Department, the Provence Alpes Côtes d'Azur Region, Silva Mediterranea from the Food and Agriculture Organization of the United Nations, and the industry Fibre Excellence Tarascon.

\section{References}

Arianoutsou M, Thanos C (2004) MEDPINE 2: Ecology of Mediterranean pines-Chania, Crete, 8-13 September 2002-foreword. Plant Ecol 171:1. doi:10.1023/B:VEGE.0000029479.56646.8b

Boulant N, Garnier A, Curt T, Lepart J (2009) Disentangling the effects of land use, shrub cover and climate on the invasion speed of native and introduced pines in grasslands. Diversity Distrib 15:1047-1059. doi:10.1111/j.1472-4642.2009.00604.x

Coutts SR, Caplat P, Cousins K, Ledgard N, Buckley Y (2012) Reproductive ecology of Pinus nigra in an invasive population: individual and population level variation in seed production and timing of seed release. Ann For Sci. doi:10.1007/s13595-0120184-5

de la Mata R, Voltas J, Zas R (2012) Phenotypic plasticity and climatic adaptation in an Atlantic maritime pine breeding population. Ann For Sci. doi:10.1007/s13595-011-0173-0

de-Miguel S, Pukkala T, Assaf N, Bonet JA (2012) Even-aged or uneven-aged modelling approach?-A case for Pinus brutia. Ann For Sci. doi:10.1007/s13595-011-0171-2

Fady B (2012) Biogeography of neutral genes and recent evolutionary history of pines in the Mediterranean Basin. Ann For Sci (in press)

Keeley JE (2012) Ecology and evolution of pine life histories. Ann For Sci. doi:10.1007/s13595-012-0201-8 
Leone V, Lovreglio R (2007) Proceedings of the International Workshop MEDPINE 3: Conservation, Regeneration and Restoration of Mediterranean Pines and their Ecosystems. Options Méditerranéennes: Série A. Séminaires Méditerranéens, no. 75. ISBN 285352-356-X. Bari: CIHEAM-IAMB, Proceedings of the International Workshop, 2005 Sept 26-30, Bari (Italy) 221 p.

Maia P, Pausas J, Vasques A, Keizer J (2012) Fire severity as a key factor in post-fire regeneration of Pinus pinaster (Ait.) in Central Portugal. Ann For Sci. doi:10.1007/s13595-012-0203-6

Piermattei A, Renzaglia F, Urbinati C (2012) Recent expansion of Pinus nigra Arn. above the timberline in the Central Apennines, Italy. Ann For Sci. doi:10.1007/s13595-012-0207-2

Poirazidis K, Zografou K, Kordopatis P, Kalivas D, Arianoutsou M, Kazanis D, Korakaki E (2012) A GIS-based integrated methodological approach to predict post-fire Aleppo pine regeneration at a regional scale. Ann For Sci (in press)

Rigolot E, Boivin T, Dreyfus P, Fernandez C, Huc R, Lefèvre F, Pichot C, Valette JC (2012) Les Pins méditerranéens Conservation, écologie, restauration et gestion: défis dans un contexte de changements globaux. Medpine 4. Forêt Méditerranéenne 33:3-18

Sheffer E (2012) A review of the development of mediterranean pineoak ecosystems after land abandonment and afforestation: are they novel ecosystems? Ann For Sci. doi:10.1007/s13595-0110181-0

Vasques A, Maia P, Pedro M, Santos M, Vallejo R, Keizer J (2012) Germination in five shrub species of maritime pine understorydoes seed provenance matter? Ann For Sci. doi:10.1007/s13595012-0206-3 